Matteo Capponi

\title{
'A Gesture That Reveals Itself As a Gesture: Thinking About the Metatheatricality of the Body in Greek Tragedy'
}

This chapter aims to question the metatheatricality of the body. Does the concept make sense, and is it relevant in the case of ancient tragedy? When the very notions of metatheatre and metatheatricality are controversial, ${ }^{1}$ the answer will depend on the definitions we give for these terms, as well as for gesture. But the mere fact that we are asking these questions enriches our reflections on ancient drama, as I hope to show at the end of this chapter with an analysis of a scene from Euripides' Orestes. ${ }^{2}$

Do body movements have a metatheatrical dimension in Greek tragedy? Or, to borrow Pellegrini's definition of metatheatre in the Oxford Companion to Theatre and Performance, does gesture help make a play 'a self-reflexive drama or performance that reveals its artistic status to the audience'? ${ }^{3}$ Does gesture show in any way an 'aesthetic self-consciousness'?' Given the specific nature of gestures, designated as schemata in Greek theatre, these issues are of great interest, as we shall see. Yet, the question being asked does not refer to the original idea of metatheatre as a genre in itself, like tragedy, comedy, and so forth. ${ }^{5}$ It takes into consideration the fact, noted by Andrés Pérez-Simón, that 'scholars [. . .] have advocated in recent years the adoption of the term "theatrical" or "theatricalist" in lieu of the more popular "metatheatrical", ${ }^{6}$ In other words, metatheatricality as a 'property' is what is considered here, i.e. the 'self-consciousness of enunciation,' as described by Pavis in his Dictionary of the Theatre:

\footnotetext{
1 In his Dictionary of the Theatre, Pavis (1998) presents four major definitions of metatheatre/ metatheatricality. However, the term does not appear in his Dictionnaire de la performance théâtrale et du thêâtre contemporain (2017). Instead, Pavis reports it under the rubric 'autoreflexibility'. See also Pérez-Simón (2011), who revisits the basis of the concept.

2 This chapter is a continuation of my $\mathrm{PhD}$ thesis, Capponi (2020a), dedicated to the various relations between gesture and speech in ancient Greek drama. I warmly thank Magali de Haro Sanchez and Jon Wilcox for their excellent translation and editing of this article from the original French and for their valuable advice.

3 Pellegrini (2010) s.v. metatheatre.

4 Pellegrini (2010) s.v. metatheatre.

5 The founding work on the concept of metatheatre is Abel (1963). Rosenmeyer (2002), which we will often refer to, offers an excellent summary and a sharp critique.

6 Pérez-Simón (2011) 4.
} 
Metatheatricality is a fundamental property of all theatrical communication. 'Operation Meta' in theatre consists in taking the stage and everything on it - actor, scenery, text as objects equipped with a demonstrative sign of denial ('it is not an object, but a meaning of the object'). Just as poetic language designates itself as an artistic device, theatre designates itself as a world already tainted by illusion. ${ }^{7}$

According to Pavis, gestures, as participating in 'theatrical communication,' should therefore possess this 'demonstrative sign of denial'. However, the very principle of a metatheatricality of gesture is not self-evident; Pavis, as we can see, does not refer to it clearly. Neither are references to gestures among the 'principal features which according to Abel set metatheatre apart from tragedy, ${ }^{, 8}$ as Rosenmeyer notes in an article in which he clearly criticizes the differing criteria used by Lionel Abel, the founder of the concept of metatheatre. Nor is gesture mentioned among the 'four figures of metatheatrical play commonly found in ancient drama, ${ }^{9}$ outlined by Kathryn Gutzwiller in her essay on Menander: 'direct reference to staging or performance, tragic quotations and parallels, allusion to technical dramatic terminology, use of disguise and deceit'. ${ }^{10}$ These figures, except for the last, are based on textual elements.

Yet, we can immediately see that gesture is not, in fact, missing. With respect to these four figures, we can readily imagine a deictic gesture being made on stage to support an allusion to the performance or to a technical element; we can see a tragic 'pose' - what ancient Greeks would have called a schema being welcome or even necessary to reinforce a tragic quotation; and we know the use of a disguise or ruse goes hand in hand with body language. In these instances, gesture is far from anecdotal. Rather, it is very useful in completing the break with the 'theatrical illusion,' or at least in reinforcing this process by which 'theatre [...] self-consciously calls attention to itself as theatre'. ${ }^{11}$ We can therefore take the opportunity to deepen the question in the context of this volume, since one of its aims is to question the definitions and limits of the concept of metatheatre.

It would be inaccurate to say that gestures were never understood from a metatheatrical perspective in ancient sources. However, scholars have proven more inclined to focus on the very mention of gestures in playscripts. In the 1930s,

7 Pavis (1998) s.v. metatheatre. Rosenmeyer (2002) 98 mentions it too: 'The hermeneutics practiced in metatheatre is often couched in the language of two virtually synonymous terms, "self-consciousness" and "reflexivity" (or "self-reflection").'

8 Rosenmeyer (2002) 88.

9 Gutzwiller (2000) 102.

10 Gutzwiller (2000) 102.

11 Gutzwiller (2000) 102. 
Gone Capone, in her work on Greek tragedy, indirectly acknowledged a metatheatrical function to gestures by giving them the role of 'internal stage directions'. ${ }^{12}$ In each play in the ancient Greek corpus, Capone distinguishes an 'informative intention', which seems to her to be intended for spectators, from a 'didascalic intention' intended for actors. This idea has not lasted, and it is no longer believed that gestures mentioned in a playscript only serve as technical indicators. Nevertheless, Capone's approach points to the fact that these occurrences have a self-referential value, which means they describe the action in progress by referring to both the gestures of characters and to their realization by actors. Besides being a mine of useful references, another point of interest in Capone's survey is that it offers an inventory of the types of gestures performed on stage. Capone indexes thirty-five 'gestures, attitudes, scenic uses, which recur in tragedies, ${ }^{, 13}$ and in doing so, highlights the great scope of gestures performed, from 'kissing' to 'breathing,' to 'touching,' 'crowning,' or 'dragging by the hair'.

A decade later, a similar approach was taken by Anna Spitzbarth in her 1946 work, Untersuchung zur Spieltechnik der griechischen Tragödie. However, in this case, the author attempted to define more precisely the nature of the gestures performed on stage. She arranged the gestures she identified into different categories by first identifying 'single gestures,' 'complex gestures,' and 'spatial movements on stage'. ${ }^{14}$ She then divided these gestures into thirteen categories, which cover, for example, gestures of salutation, gestures of mourning, and acts of violence. ${ }^{15}$ Spitzbarth has thus shown that not all gestures are of the same nature or have the same scale on stage: a simple deictic gesture contrasts, for example, with the complete and ritual act of supplication.

We can glean from the work of Capone and Spitzbarth, then, that there existed a considerable number of gestures performed on the ancient stage and that these gestures differed in their nature and function. We can further our inquiry on the basis of these considerations. In his 1978 work Greek Tragedy in

12 Capone (1935) 52, my translation.

13 Capone (1935) 112-120, my translation.

14 My translation.

15 Spitzbarth's thirteen categories of gesture are: (1) Zeigegebärde, 'pointing gestures' (2) Enthüllen und Verhüllen, 'unveiling and veiling' (3) Anrufung, 'invocation' (4) Lauschen und Spähen, 'eavesdropping and peeking' (5) Begrüssung und Abschied, 'greetings and farewells' (6) Trauer, 'mourning' (7) Vorgänge der Gewalt, 'acts of violence' (8) Formen des Auf- und Abtretens, 'forms of appearance and departure' (9) Tätigkeit der Statisten, 'activities of the extras' (10) Gerätspiel, 'playing with props' (11) Doppelvorgänge, 'doubling' (12) Rollencharakteristik, 'role characteristics' (13) Darstellung seelischer Vorgänge, 'representation of emotional processes' (my translation). 
Action, a seminal text in the emergence of performance studies, Oliver Taplin also made distinctions between different types of gestures, among other things depending on the connection between the text and the actions performed on stage. His initial remarks are general:

Apart from exits and entrances, the range extends from the simple gestures which emphasize speech - movements and positioning of hands, feet or head - to rapid and fluent actions such as running, fainting or raving in madness. In between come kneeling, embracing, veiling, drawing swords, handing over objects, approaching, fleeing and so on and so forth. ${ }^{16}$

Hereafter, Taplin identifies a category of gestures connected more fundamentally to the plot and to the show:

No doubt conventional gestures and small movements often accompanied the speech of Greek tragedy. [. . .] But these run-of-the-mill bodily movements, while they are a concern for the actor and producer and while their economy and appropriateness are essential for a good performance, are not my chief concern here. I am preoccupied with the unique action which is brought about by, and which often epitomizes, the dramatic impact of a particular moment. [. . .] There is still a large residue: sitting and lying down, running, kneeling, supplicating, embracing, striking, bowing the head, looking away and so on. ${ }^{17}$

For Taplin, anecdotal gestures or 'run-of-the-mill bodily movements' thus contrast with particular 'unique actions' depicted by the text. A whole scene can be articulated around actions of this latter type, where the gesture carries the 'dramatic impact of a particular moment'. This would justify the repeated mention of such gestures in the text.

A different point of view is adopted by Mario Telò who, in two successive studies, ${ }^{18}$ attempts to lay the foundation of a 'grammar of gesture' based on 'the verbal trace of a gesture, the principal starting point for any attempt at reconstruction'.$^{19}$ For his part, Telò tries to identify in the tragic corpus the traces of actions such as falling to the ground and getting up, covering oneself and uncovering one's face, and supplicating. In doing so, he succeeds in reconstituting the staging of these actions. However, according to Telò, these gestural references are 'involuntary stage indications, not deliberately inserted by the author in order to inform the spectators about the actors, but presented in the text as a natural verbal accompaniment to the ongoing action on stage, ${ }^{20}$ Like Taplin, Telò highlights some movements that play a special role in the dramaturgy of

16 Taplin (1978) 15.

17 Taplin (1978) 58.

18 Telò (2002a); (2002b).

19 Telò (2002a) 15-16, my translation.

20 Telò (2002a) 11, my translation. 
performance. By contrast, he seems to miss the point in considering the gestural references in the text as a 'natural accompaniment' to their enaction, since the notion of 'natural' here has no epistemological or dramaturgical basis. Neither informative nor redundant, the gestural references from which Telò's staging and 'grammar of gesture' result invite us, on the contrary, to seek there the dramaturgical intention of the poet, which finds fulfillment in performance. As such, it is worth reminding that Aristotle, in Poetics, recommends that the poet composes by resorting to the visualization of the scene and even to the schemata (here translated as 'gestures'):

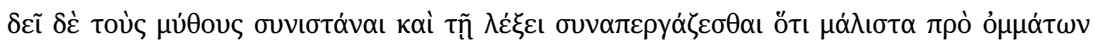

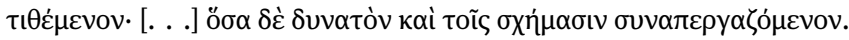

In constructing plots and completing the effect by the help of dialogue the poet should, as far as possible, keep the scene before his eyes. [. . . ] The poet should also, as far as possible, complete the effect by using the gestures. ${ }^{21}$

By choosing to highlight some gestures and not others, the playwright alerts his audience/listener. He prepares them to enjoy the spectacle of an action amplified by its staging. Taplin expresses this principle in very simple terms: 'When the playwright draws attention to a stage action, we should take up the invitation and consider what the significance of that action is meant to be. ${ }^{, 2}$ These words cohere well with those of Pavis; they invite us to see in the process of theatrical mimesis not the imitation of daily acts, but the production of 'demonstrative sign[s] of denial'. ${ }^{23}$ The ancient mimesis implies a recreation, a re-presentation, in the literal sense of the term. ${ }^{24}$ The gestures proceed from the same logic as the dramatic text, as described by Florence Dupont (in whose description we also see the reappearance of the notion of denial):

D’une façon générale le théâtre antique ne représente pas sur scène des conversations, même transposées, il les déconstruit pour reconstruire un dialogue théâtral. Mais cette déconstruction est à l'œuvre dans le texte lui-même, elle est elle-même spectacle et l'intelligibilité du dialogue théâtral passe par la reconnaissance du modèle selon une procédure de dénégation qui l'identifie pour l'écarter ou le détourner au moyen du code théâtral. (. . .) Une déconstruction est une analyse, et finalement chaque théâtre antique implique une linguistique..$^{25}$

21 Aristotle, Poet. 1455a22-1455a32, transl. Fyfe (1932).

22 Taplin (1978) 19.

23 Pavis (1998) s.v. metatheatre.

24 This is how Dupont-Roc and Lallot (1980) translate the term mimesis in their commentary on Aristotle's Poetics.

25 Dupont (2000) 147. 
Indeed every ancient theatre play involves 'une linguistique' - namely, a discourse upon language, a metadiscourse. In a similar way, every ancient theatre play also involves a discourse upon gestures, that is to say a metagestuality. The truth is, whether we talk about metagestuality, metatheatricality, or selfreferentiality, we are dealing with the same principle. We see the shape it takes in the case of the ancient theatre play: to return to Pellegrini's definition of metatheatre, the self-referential gestural terms also, referring to the gestures of the performance, 'reveal their artistic status to the audience' and imply an 'aesthetic self-consciousness' insofar as they highlight specific actions among all those performed on stage.

The follow-up to this research, by which we could achieve concrete results, would therefore be to observe more closely the process of deconstruction and reconstruction mentioned by Dupont, to see what types of gestures (or schemata) are prioritized and how the text interacts with the gestures performed on stage. However, this is not the place to undertake such a large-scale study, especially since efforts in this direction have already been made in the case of specific gestures. ${ }^{26}$ Rather, let us deepen the concept of metatheatricality by turning to a study by Patricia Legangneux, published in the same volume of Lalies as Dupont's, which examines the gesture of supplication. Recalling the principle of double theatrical enunciation, Legangneux explains that the logic of speech acts and corresponding gestures changes as soon as it incorporates a spectacular dimension:

Une supplication théâtralisée n'est plus performative, mais mimétique. Elle présente d'autres enjeux que la supplication rituelle entre deux protagonistes, puisqu'elle se situe dans le cadre d'une double énonciation : la supplication s'adresse au partenaire sur scène sous le regard du public. ${ }^{27}$

As a result, Legangneux explains the transformation that both speech and gesture undergo:

26 For example, Taplin (1977) has studied the entries and exits of the characters in the work of Aeschylus and Telò (2002a), as we said, has focused on falling to the ground and getting up, covering oneself and uncovering one's face.

27 Legangneux (2000) 176. Regarding double enunciation, Dupont (2000) 145 notes: 'Le personnage de théâtre est donc installé dans une double énonciation, correspondant à deux destinataires. Le public est toujours là, l'autre interlocuteur n'est présent que dans les dialogues. C'est pourquoi nous appellerons "première énonciation" celle dont le public est le destinataire, "seconde énonciation" celle dont un autre personnage est destinataire'. This logic of first and second utterances likewise applies to gestures: the first recipient of gestures is always the audience. 
Un autre intérêt de ces scènes est la façon dont le code linguistique que nous avons décrit précédemment est exhibé au théâtre : l'énoncé est amplifié et suit des modèles rhétoriques argumentatifs, surtout chez Euripide ; les gestes effectués nécessitant des jeux de scène précis sont commentés longuement, ce qui nous permet de penser qu'ils étaient effectivement réalisés. ${ }^{28}$

Further, the author adds: 'La supplication rituelle est devenu une convention théâtrale avec des règles d'efficacité spectaculaire. ${ }^{29}$ And she concludes: 'La mimesis tragique de la supplication est donc une transposition distanciée, à la fois critique et pathétique, d'un rite codifié. ${ }^{30}$ It is this act of transposition and criticism that gives tragic gestures a metatheatrical dimension. Strictly speaking, this is not a gesture performed on stage. This is the theatricalization of a gesture, determined by the textual elements, and which the term schema accurately designates. To paraphrase Pavis: 'It is not a gesture, but a meaning of the gesture. ${ }^{31}$ And in the following sentence, the word 'theatre' refers as much to the speech as to scenic gestures: 'Just as poetic language designates itself as an artistic device, theatre designates itself as a world already tainted by illusion. ${ }^{32}$ In short, one can apply to staged gestures the same reflection that Neumann applies to gestures in the visual arts. In his in-depth study of the Gesten und Gebärden in der griechischen Kunst, he concludes: 'The expressive function of their various manifestations, which in real life is often concealed and usually not fully realized, is emphasized in the visual arts in a convincing and obvious way. ${ }^{33}$ Not only do the gestures/schemata performed on stage belong to another logic and obtain a realization other than those of everyday life, but in addition they benefit from the spotlight offered by the self-referential terms, so to speak.

Having reached this point, can we safely conclude that gestures are metatheatrical? If we mean by metatheatre, following Gutzwiller, 'theatre that selfconsciously calls attention to itself as theatre, often for the purpose of playing with the distinction between the fiction of the play and the reality of perform-

28 Legangneux (2000) 177.

29 Legangneux (2000) 178.

30 Legangneux (2000) 187.

31 The original sentence is: 'It is not an object, but a meaning of the object.' Pavis (1998) 211.

32 Pavis (1998) 211.

33 Neumann (1965) 1, my translation. Original: 'Die im wirklichem Leben oft verdeckte und meist nicht voll realisierte Aussagefunktion ihrer verschiedenen Erscheinungsweisen wird in den bildenden Kunst in überzeugender und sinnfälliger Weise herausgestellt.' 
ance, ${ }^{34}$ then the answer is no. There is, strictly speaking, no self-reflexive intention in the staging of gestures, no desire to expose the theatrical codes. Moreover, as Rosenmeyer reminds us, no play in ancient theatre really makes this fact a central element. It leads him to this conclusion:

It is evident that 'metatheatre' has, in the wake of Abel's overload, been employed to cover too many different moves, and to elicit responses that undervalue the traditional inventiveness and the wonderful immediacy of the emotional power of theatre. ${ }^{35}$

On the other hand, if we consider a broader understanding of metatheatricality, namely if we see it as inherent in any theatrical production, then yes, gestures play a role in it. The logic is that highlighted by William Egginton in How the World Became a Stage:

There can be no theatre that is not already a metatheatre, in that in the instant a distinction is recognized between areal space and another, imaginary one that mirrors it, that very distinction becomes an element to be incorporated as another distinction in the imaginary space's work of mimesis. ${ }^{36}$

The objective would be to observe by which linguistic and visual means gestures on stage are distinguished from their everyday reference. To use the title of this contribution: how does a gesture reveals itself as a gesture? We will see that this perspective sheds light on certain aspects of ancient theatre. Previous studies have provided us with some answers. As much as those of Telò and Legangneux, those of Taplin have highlighted certain specific gestures more apt to constitute the heart of a scene, to be theatrical, both deconstructed and reconstructed. The process they follow is an amplification, which Pavis describes in the following terms: 'Dès que le mouvement se fait expressif, dès qu'il s'intensifie, il devient un geste esthétique. ${ }^{37}$

This process takes a particular turn in the case of ancient theatre, whose gestuality is not that of the theatre to which we are accustomed. Influenced by dance, ${ }^{38}$ it is a theatre made of poses and attitudes, called schemata, alternating with movements or phorai. We could rather find a correspondent in oriental theatres, Japanese kabuki theatre or Indian kathakali. The entry for 'Poses' in

34 Gutzwiller (2000) 102.

35 Rosenmeyer (2002) 106-107.

36 Egginton (2003) 74, quoted by Pérez-Simón (2011) 4.

37 Pavis (2017) s.v. movement.

38 'Greek dance was not as specialized as today and the distinction between dance, acting, mime, and gesture was blurred.' Llewellyn-Jones (2014) s.v. poses. For an attempt to differentiate between dance and acting schemata, see Capponi (2021a) 312-315. 
The Encyclopedia of Greek Tragedy describes this type of theatricality, consisting of a 'series of movements with a pose or with a frozen gesture'. ${ }^{39}$ Following a comparison with acting in kabuki theatre, the Encyclopedia entry defines it as 'a codified theatrical language performed not simply through speech, but through movement and gesture'. ${ }^{40}$ In all cases where these schemata appear, we are therefore dealing with codified gestures, relating to an aesthetic shared by sculpture and iconography. ${ }^{41}$ We also find a trace of this (metatheatrical) code in comedy, in the case of tragic parodies: Dionysos imitating the schema of Heracles in The Frogs (the term itself appears in verse 86); the roles played and range of traditional images employed by Euripides and his parent in the Thesmophoriazusae to try to escape the guard (Helen, Menelaos, Echo, Perseus and Andromeda); or Dikeopolis in The Acharnians, who borrows the costume and speech but also the pose of Telephus, by taking hostage a sack of coal to make his argument before the chorus! ${ }^{42}$

In each of these cases, self-referential terms are used to highlight the image produced. One direction to take for further research would be to list all identifiable schemata and then to observe how they are indicated and dramaturgized by the text and, at the same time, integrated into the action. Capone, once again, has led the way by listing in her 'glossary of mimicry and theatrical terminology' twenty-two 'schemata', as she calls them, which gather such terms as 'arrogance,' 'blindness,' and 'old age'. Capone does not, however, explain clearly upon what criteria she bases her selection.

If one wants to demonstrate the relevance of the concept of (meta)theatricality in the case of tragic gestuality, it would be more promising to look at gestures that do not belong to these traditional schemata. It is a question of reflecting on less obvious gestures, ones we will not find in the lists of Capone or Spitzbarth, ones set aside by Taplin. These gestures exist and, paradoxically, they can also be found at the heart of a scene. In a study devoted to physical contact in tragedy, Maarit Kaimio $^{43}$ evokes such gestures: she adopts a transversal perspective, which

39 Llewellyn-Jones (2014) s.v. poses.

40 Llewellyn-Jones (2014) s.v. poses. The book by Capponi (2020a) focuses on the relationship between schemata, modalities of statements, and speech acts.

41 On this polysemy of the schemata, see Catoni (2005).

42 See also Llewellyn-Jones (2014) s.v. poses: 'Aristophanes however provides specific evidence for actors (not dancers) employing schemata,' for example Philocleon in The Wasps who, imitating Phrynichus, 'performs a number of schemata associated with early styles of tragic performance'.

43 Kaimio (1988). 
encompasses ritual gestures of supplication or greeting as much as gestures of 'nursing'. It is this last gesture that I am interested in, as it appears in a scene from the Orestes of Euripides. It is by examining this example that I hope to draw attention to an area that remains largely unresolved: that of everyday gestures, which metatheatrical reflection allows us to highlight.

In the scene that will be examined here (Or. 215-238), the beginning of a long stichomythia, Electra takes care of her brother Orestes, bedridden and sick, in the grip of delirium. The scene's purpose is, according to Martin West's commentary, 'to display the selfless mutual devotion of brother and sister'. ${ }^{44} \mathrm{I}$ adopt a method I developed in other studies, ${ }^{45}$ which consists in reconstructing the gestures performed on stage by taking into account the pragmatic elements of the utterances, as well as gestural references, but also the technical aspects of ancient theatre, as far as we know them. Regarding the latter, let us summarize them in these terms: for reasons of acoustics and optics, when an actor speaks or sings, he must remain motionless, the mask turned toward the audience as much as possible, adopting for example a defined schema; for the same reason, gestures must take place between spoken replies, indicating at the same time which character is about to speak; finally, gestures must be made to the audience (the first recipient ${ }^{46}$ ); that is, amplified and visible at a 180-degree angle. ${ }^{47}$ Some wall-paintings found in Ephesus highlight these principles. They picture dramatic figures identified by titles of plays. Besides the Sicyonioi or the Perikeiromene of Menander, one of them could even refer to our scene, since the caption identifies the play as Orestes. ${ }^{48}$ The actors' costumes rather belong to the Hellenistic period, but we clearly recognize Orestes lying across his bed and Electra standing by his side. Both face the public and execute gestures in its direction [Figure 1].

In what follows, I present the spoken lines in this scene in turn and try to visualize the gestures that accompany them.

Orestes has just woken up; he is lying on his bed, parallel to the skene. He has thanked Hypnos, the Sleep, but now wonders out loud, because he no longer remembers anything (215-216):

44 West (1987) 195.

45 See Capponi (2020a) and (2020b).

46 Other characters, on or off stage, being the second recipient.

47 For an explanation of these principles, see Capponi (2020b) 345-349.

48 See Strocka (1977) fig. 65.; Zimmermann/Ladstätter (2010) 117 fig. 205. See also SEG 29.1118. 


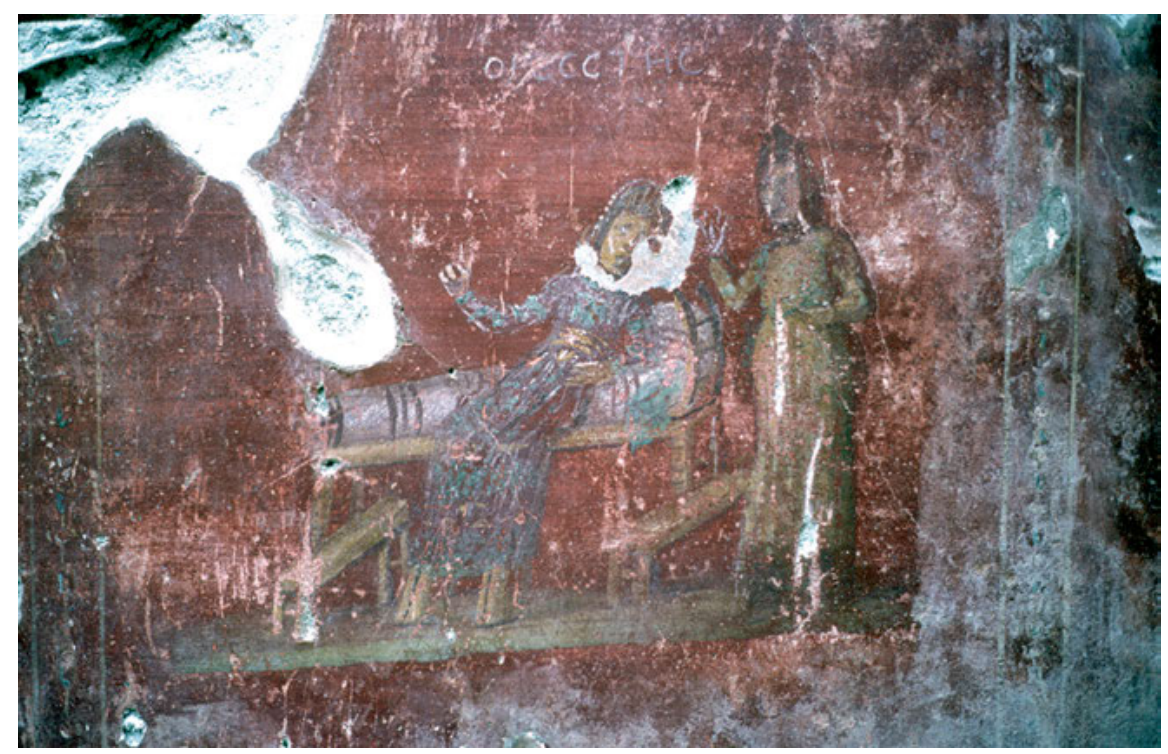

Figure 1: Mural fresco from the Terrace Houses in Ephesus. By courtesy of the Austrian Archaeological Institute | Austrian Academy of Sciences.

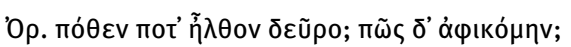

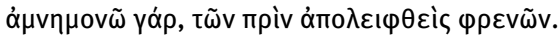

Or. Where have I come from? How am I here? For I have lost all previous recollection and remember nothing. ${ }^{49}$

Electra is by his side. She speaks to her brother and therefore extends an arm toward him. Then her gesture becomes interrogative to accompany her question (217-218).

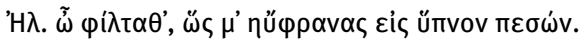

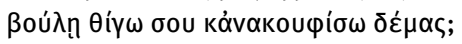

El. My dearest, how glad I was to see you fall asleep! Do you allow me to touch you and lift your body?

\section{Orestes reaches out to Electra (219-220).}

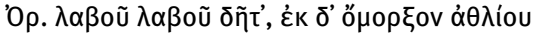

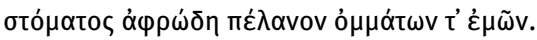

Or. Yes, take hold, take hold of me, and from this sufferer's mouth and eyes wipe off the flakes of foam.

49 Edition Diggle (1994), translation by Coleridge adapted when necessary. 
Electra wipes (with her dress?) the face of Orestes, or at least the actor indicates that he is wiping Orestes' face. The end of this gesture is marked by the expression ioou' ('There!'). Then Electra, facing the audience, comments on her action, which gives it even more weight (221-222).

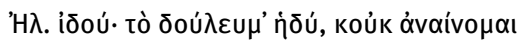

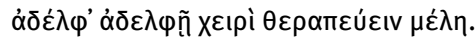

$E l$. There! The service is sweet, and I do not refuse to tend a brother's limbs with a sister's hand.

Orestes makes two requests in a row: that Electra pull him up, then that she comb $\operatorname{him}(223-224){ }^{50}$

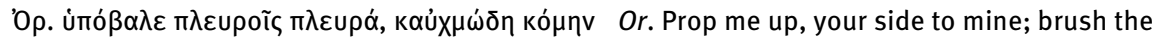

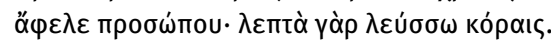
matted hair from my face, for I see dimly.

Electra takes time to get Orestes seated, leaning against him. ${ }^{51}$ Then she removes (or the actor pretends to remove) his hair which has fallen about the face. Sitting on the bed also, Electra can then speak facing the audience again, before looking back at Orestes (225-226).

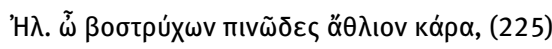

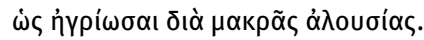

El. Ah, poor head, how dirty your hair! How savage you look, remaining so long unwashed!

Orestes sitting, his mask facing the audience, asks that Electra lay him on the couch again (227-228).

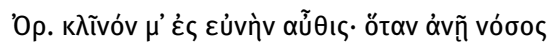

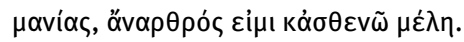

Or. Put me once more upon the couch; whenever the madness leaves me, I am unnerved and weak.

Electra gets up and makes Orestes lie down again. Here again, her gesture ends with the expression ioov'. Electra's comment highlights her patience and affection (229-230).

50 Willink (1986) 122 notes in his commentary: 'Presumably El. is to put an arm and shoulder beneath Or.'s back.' But he doesn't try to organize the order of the gestures performed.

51 Kaimio (1988) 9 emphasizes the intensity of such contact scenes: 'From the point of view of the use of theatrical space, it is probable that scenes involving physical contact were rather an exception from the usual way of acting and that they consequently had great potential theatrical effect.' This scene reverses the expected hierarchical relationship: the girl is the last support of the male hero. 


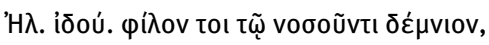

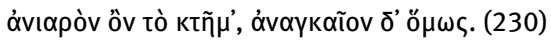

$E l$. There! His couch is welcome to the sick man, a painful possession, but a necessary one.

Orestes again asks that Electra pull him up! The repetition is almost comical. Orestes is forced to justify himself (231-232).

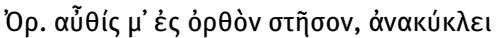
$\delta \varepsilon \dot{\mu} \mu \varsigma^{-}$

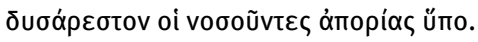

Or. Set me upright once again, turn my body round;

it is their helplessness that makes the sick so hard to please.

Instead of obeying, Electra takes the initiative and invites Orestes to get up. The

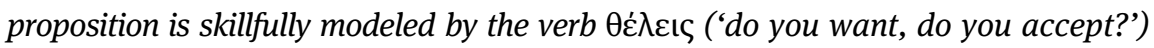
and two arguments (233-234).

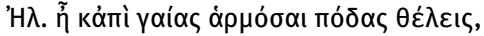

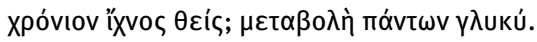

$E l$. Will you set your feet upon the ground and take a step at last? Change is always pleasant.

Orestes answers in the affirmative, with a 'semi-philosophical remark' (235-236). ${ }^{52}$

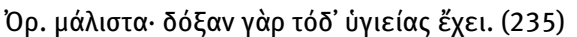

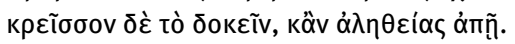

Or. Oh, yes; for that has a semblance of health; and the semblance is preferable, though it is far from the truth.

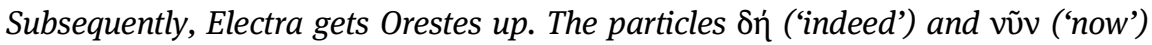
in Electra's reply confirm the end of this action, which probably lasts some time. It reveals both the weakness of Orestes and the will of Electra. It should also be noted that the resulting image, the hero supported by an ally (usually a man!), is a traditional motif. ${ }^{53}$ The scene therefore ends on a well-known but perverted schema (237-238).

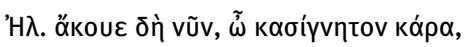

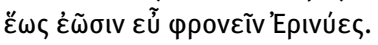

El. Hear me now, my brother, while the Furies permit you to use your senses.

52 West (1987) 197.

53 Kaimio (1988) 16: 'In scenes of supporting the wounded or caring for the sick, tragic heroes are often brought into physical contact with their helpers, either mute attendants or actors.' Kaimio cites as examples Theseus supporting Heracles in The Madness of Heracles by Euripides, Pylades accompanying Orestes to the assembly in the Orestes of the same author, and, in Sophocles' play Philoctetes, Philoctetes leaving his island supported by Neoptolemus. 
From this symbolic position, Electra resumes the dialogue, which concerns the salvation of Orestes, while Menelaos returns to Greece. But this dialogue doesn't last: a new delirium seizes Orestes, which will leave him slumped on his bed once again!

Our scene ends with Orestes getting up. It is brief, but what I wanted to show with this scene of intimacy - rather than a scene illustrating a more spectacular gesture of supplication, prayer, or exchange of philia, for example (by a handshake) - is that ultimately Taplin's distinction between 'unique actions' and 'run-of-the-mill bodily movements,' between emblematic and everyday gestures, does not necessarily hold. It does not show the diversity of gestural realizations. The gestures typically observed as a priority by scholars, as we have seen, are movements or schemata that have a dramaturgical (Capone, Taplin) or ritual (Telò, Dupont, Legangneux) function. We would look in vain in their lists for the gesture of wiping a foaming mouth (220-221) or restyling filthy hair (225-226). Yet these gestures are the very material of the scene between Electra and Orestes. They are praxic (non-verbal and non-communicative) gestures, made within an intimate sphere of care - yet the aestheticization process remains the same for them as for more traditional schemata.

Thus, this brief passage reveals to us a tendency, at least in Euripides, to stage marginal gestures, that is to say intimate or even unsightly gestures. From this point of view, Euripides once again appears innovative. It is not surprising that the only two examples of 'Sickroom Scenes' listed by Kaimio come from his work, the scene in Orestes we have just studied and a scene at the beginning of Hippolytus (Phaedra appears on her bed, in the grip of love-sickness). Kaimio comments on this: 'Such an elaborate choreography of realistic nursing, not merely of conventional gestures of support, supplication, greeting of farewell, [. . . ] is without parallel in earlier dramas that have survived. ${ }^{54}$ We will appreciate the paradox of this 'realist choreography' which echoes what we have discussed in this chapter about the gesture considered as a 'demonstrative sign of denial,' as Pavis said, i.e. as possessing a metatheatrical dimension.

Surprisingly, Euripides' approach finds an echo in what Pavis says about the contemporary scene: 'L'expérimentation, souvent anarchique et antithéorique, (. . .) fait en retour considérablement avancer notre compréhension $\mathrm{du}$ mouvement et du corps en situation de représentation. ${ }^{55}$ In the scene from Orestes at least, Euripides' dramaturgical treatment of such uncommon schemata seems to me to be part of a critical, self-reflexive approach - it is, in

54 Kaimio (1988) 20.

55 Pavis (2017) s.v. mouvement. 
a word, metatheatrical. To reinforce this hypothesis, it would be necessary to open up the perspective, to look for other occurrences of this type in Euripides, and to compare this treatment with that in Sophocles and in Aeschylus. The work remains to be done, but I am convinced that it would be enough to confirm the relevance of a metatheatrical approach to gesture. 
